\title{
Sintering and dielectric properties of a technical porcelain prepared from economical natural raw materials
}

\section{(Sinterização e propriedades dielétricas de uma porcelana técnica preparada a partir de matérias-primas naturais de baixos custos)}

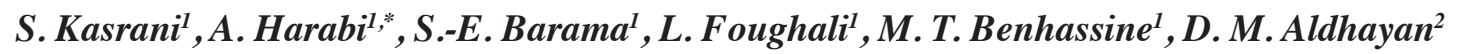 \\ ${ }^{I}$ Ceramics Lab., Faculty of Exact Science, Physics Department, Mentouri University of Constantine, \\ Constantine 25000, Algeria \\ ${ }^{2}$ Chemistry Department, Riyadh, King Saud University, Saudi Arabia \\ souad478@yahoo.fr,*harabi52@gmail.com,sebarama@usa.com,foughali_lazhar@yahoo.fr, \\ mtb25dz@gmail.com,aldhayan@ksu.edu.sa
}

\begin{abstract}
In this study, the production of a technical porcelain, for the ceramic dielectric applications by using economical natural raw materials, was investigated. The basic porcelain composition was selected consisting of $30 \mathrm{wt} \% \mathrm{kaolin}, 45 \mathrm{wt} \%$ potash-feldspar and $25 \mathrm{wt} \%$ quartz. The obtained phases in the sintered samples were investigated by X-ray diffraction, Fourier transform infrared spectroscopy analysis, and scanning electron microscopy images. It has been confirmed by these techniques that the main crystalline phases were quartz and mullite. Dielectric measurements of technical porcelains have been carried out at $1 \mathrm{kHz}$ from room temperature to $200{ }^{\circ} \mathrm{C}$. The dielectric constant, loss factor, dielectric loss tangent, and resistivity of the porcelain sample sintered at $1160^{\circ} \mathrm{C}$ were $22-25,0.32-1.80,0.006-0.07$, and $0.2-9 \times 10^{13} \Omega . \mathrm{cm}$, respectively. The value of dielectric constant was significantly high when compared to that of conventional porcelains which did not exceed generally 9.
\end{abstract}

Keywords: porcelain, kaolin, feldspar, quartz, sintering, dielectric properties.

Resumo

Neste estudo, foi investigada a produção de uma porcelana técnica para aplicações cerâmicas dielétricas pelo uso de matériasprimas naturais de baixos custos. A composição básica da porcelana foi selecionada consistindo de $30 \%$ de caulim, $45 \%$ de feldspato potássico e $25 \%$ de quartzo. As fases obtidas nas amostras sinterizadas foram investigadas por difração de raios X, espectroscopia no infravermelho com transformada de Fourier e imagens de microscopia eletrônica de varredura. Foi confirmado por estas técnicas que as principais fases cristalinas foram quartzo e mulita. Medidas dielétricas das porcelanas técnicas foram realizadas a $1 \mathrm{kHz}$ entre a temperatura ambiente de $200{ }^{\circ} \mathrm{C}$. A constante dielétrica, fator de perda, tangente de perda dielétrica e resistividade da amostra de porcelana sinterizada a $1160{ }^{\circ} \mathrm{C}$ foram $22-25,0,32-1,80,0,006-0,07$ e 0,2-9 $\times 10^{13} \Omega . c m$, respectivamente. $O$ valor de constante dielétrica foi significativamente alto quando comparado ao de porcelanas convencionais que geralmente não excede 9. Palavras-chave: porcelana, caulim, feldspato, quartzo, sinterização, propriedades dielétricas.

\section{INTRODUCTION}

The use of traditional ceramics, using raw materials instead of industrial chemicals is becoming of more and more interest mainly due to the lower price of the raw material available. Algeria is one of the countries in the world that have abundantly available raw materials, such as calcium carbonates $\left(\mathrm{CaCO}_{3}\right)$, dolomite $\left(\mathrm{CaCO}_{3} \cdot \mathrm{MgCO}_{3}\right)$, bones (natural derived hydroxyapatite $\left[\mathrm{Ca}_{10}\left(\mathrm{PO}_{4}\right)_{6}(\mathrm{OH})_{2}\right]$, kaolin, feldspar and quartz. Many works have already been published for valorizing these native raw materials, for the production of advanced ceramics [1-3], bioceramics [4-6], and ceramic membranes [7-15]. In this way, an attempt has been done in order to use two types of kaolin (halloysite type and Tamazart), feldspar and quartz local raw materials for porcelain production. Porcelain insulators and porcelain shells are important devices in the operation of plants and transformer substations insulation and wire supporting [16]. The electrical porcelains are usually prepared by using pressure. However, in many cases, the use of glass forming components to ceramic samples result in decrease in firing temperature, amount of crystalline phases due to their dissolution in the glass phase during sintering, and mechanical and thermal properties of the porcelain. The manufacture of porcelain having ameliorated properties at low sintering temperatures is possible up to certain limits. Indeed, the properties of the porcelain are mainly determined by the presence of sufficient quantity of well-crystallized mullite. The sintering temperature of porcelain is therefore connected 
to the development of the processes of mullite formation in the clay-nonplastics-flux system, i.e. the firing temperature of the porcelain must not be lower than the temperature at which the mullite forming processes can be completed (not below 1150 to $\left.1200{ }^{\circ} \mathrm{C}\right)$ [17].

The utilization of ceramic materials such as electrical insulators goes back to 1850 when Werner von Siemens introduced in the construction of electrical air lines the use of electro-technical porcelains. During this long period of time, it has been realized that several characteristic properties of porcelain (e.g., mechanical strength, high-power dielectric strength, and corrosion resistance) as a ceramic product cannot be obtained in other materials. Electrical porcelains can be classified as follows based on its purpose and properties [18, 19]: i) normal high-voltage porcelains used in the production of high-voltage line and apparatus insulators; ii) high-voltage porcelains with an increased quartz content used to make highvoltage apparatus insulators with improved electromechanical properties; iii) high-voltage alumina porcelains for high-voltage apparatus insulators with elevated mechanical strengths; iv) low-voltage porcelains used in the production of insulators and insulating parts for plants up to $500 \mathrm{~V}$ generating direct and alternating current and weak current plants [20]. Today, the growing demand for porcelain in the field of electrical engineering, caused by the importance of electric energy in modern society, motivates many research projects in order to obtain the best properties for the requirements and applications of porcelain insulators [21].

The potential uses of electrical ceramics in many applications are determined by its dielectric properties. For example, dielectrics with dielectric constant above 12 are generally materials for capacitors and transducers. The ceramic capacitors are one of the most widely used discrete electronic components that play a very important role in electronic industries. In the recent years, a rapid development in the ceramic capacitor technology has been achieved to meet the needs of advancement in microelectronics and communication. It is envisaged that more applications of ceramic capacitors will be found in future [7]. In the present investigation, the dielectric properties of the technical porcelain were studied. Consequently, this part is devoted only to the sintering and the dielectric properties of technical porcelains. In the present investigation, preparation of technical porcelains using Algerian raw materials and dielectric properties was carried out. Dielectric constant $\left(\varepsilon^{\prime}\right)$, loss factor ( $\left.\varepsilon^{\prime \prime}\right)$ and dielectric loss tangent $(\tan \delta)$ were studied. Finally, qualitative estimation of quartz and mullite has been done to study the dielectric properties of the selected composition using X-ray diffraction studies, Fourier transform infrared spectroscopy analyses, and scanning electron microscopy (SEM) images.

\section{EXPERIMENTAL PROCEDURE}

The main raw materials used for the preparation of the porcelain were Djebel Debbegh kaolin, halloysite type (KDD2), Tamazart kaolin (KT2), Ain Barber potassium feldspar, and Ben Azouz quartz sand. All these raw materials presented in this study were derived from deposits in Algeria. Chemical composition is an important factor because of its effects on ceramic properties. The chemical compositions of the three used raw materials were determined by X-ray fluorescence spectroscopy. This study investigated a unique porcelain type percentage composition of $30 \mathrm{wt} \%$ kaolin (20 wt $\%$ KDD2 and $10 \mathrm{wt} \% \mathrm{KT} 2), 45 \mathrm{wt} \%$ feldspar and $25 \mathrm{wt} \%$ quartz.

The raw materials pulverized into powders ready for batching were used: raw materials were wet milled and homogenized in a modified milling system for $6 \mathrm{~h}$ to obtain the typical size distribution used in industrial productions. The main characteristics of this original milling system are detailed elsewhere [22]. It is mainly composed of 4 parts: a metallic cylinder, a teflon bottle, a motor, and a rotational system. The latter makes the cylinder to rotate with a constant speed. In order to avoid the adhesion of the powder on its sides, the bottle has been placed obliquely in the middle of the cylinder within an angle $\alpha$. This device has also four springs fixed at 4 corners of its support so as to allow the bottle to vibrate gently or strongly. This system works smoothly and silently, contrarily to the usual noisy vibratory milling system due to its motor. These last two characteristics are the origin of the obtained multidirectional rotation. As a result, powerful and continuous collisions may occur between the hard milling balls and the powder particles which substantially reduce the powder particle size. Many interesting published works have used this original milling system [23-25]; they concern hydroxyapatite based ceramics [26-28], wollastonite [29-31], diopside [32-34], anorthite [35, 36], and others [3742]. By drying, the test specimens for firing tests, shaped as discs of about $13 \mathrm{~mm}$ diameter and about $2 \mathrm{~mm}$ thickness, were obtained after uniaxial pressing of powders at 75 $\mathrm{MPa}$. Subsequently, the compacts were sintered at different temperatures $\left(1080\right.$ to $\left.1260{ }^{\circ} \mathrm{C}\right)$ for $2 \mathrm{~h}$. A constant heating rate of $5{ }^{\circ} \mathrm{C} / \mathrm{min}$ was maintained in each firing. The samples were left inside the oven to naturally cool down until room temperature. For the dielectric properties characterization, only samples sintered at $1160{ }^{\circ} \mathrm{C}$ were selected.

Different techniques were used to investigate the properties of samples. The morphology, microstructure of the raw materials and samples were observed using a SEM (Hitachi, JSM-6301 F, Japan) working at $7 \mathrm{kV}$ as accelerating voltage. Before SEM observation, all samples were gold coated. Phase compositions of prepared samples were identified by using X-ray diffraction (XRD, Bruker, D8 Advance, Germany) with a $\mathrm{CuK} \alpha$ radiation $(\lambda=0.154$ $\mathrm{nm}$ ) and a Ni filter, working voltage of $40 \mathrm{kV}$, and working current of $30 \mathrm{~mA}$. Fourier transform infrared spectroscopy (FTIR, Perkin Elmer, Spectrum BX LX 185255) was also used for samples characterization. The density of green and dried specimens was geometrically determined from their weight and dimensional measurements, which were accurate to $\pm 0.001 \mathrm{~g}$ and $\pm 0.01 \mathrm{~mm}$, respectively. In order to create a conduction path for electrical measurements on the samples, electrodes with silver paste on the top and bottom faces were used. The electrodes were fired at $300{ }^{\circ} \mathrm{C}$ for $20 \mathrm{~min}$ with 
a heating rate of $5{ }^{\circ} \mathrm{C} / \mathrm{min}$. Subsequently, all measurements were undertaken at a temperature range from 20 to $190{ }^{\circ} \mathrm{C}$ on a LCR meter connected to a furnace with a heating rate of $5{ }^{\circ} \mathrm{C} / \mathrm{min}$ (Fig. 1). The dielectric constant was calculated as the measured capacitance multiplied by the sample geometrical factor. The dielectric constant $\left(\varepsilon^{\prime}\right)$ and loss factor $(\varepsilon ")$ were determined from the following equations:

$$
\begin{aligned}
& \varepsilon^{\prime}=\mathrm{C} / \mathrm{C}_{0}=\mathrm{C} \cdot \mathrm{l} /\left(\varepsilon_{0} \cdot \mathrm{A}\right) \\
& \varepsilon^{\prime \prime}=\varepsilon^{\prime} \cdot \tan \delta
\end{aligned}
$$

where $\mathrm{C}_{0}$ is the capacitance of a two-electrode system with air as the dielectric, $\mathrm{C}$ is the capacitance with the sample as a dielectric, 1 is the thickness of the sample, A is the effective area between the electrodes, and $\varepsilon_{0}$ is the free space permittivity. The dielectric loss tangent $(\tan \delta)$ was given directly by the instrument. The resistivity $(\rho)$ values were calculated as the ratio:

$$
\rho=1 / \sigma=1 /\left(\omega \cdot \tan \delta \cdot \varepsilon^{\prime} \cdot \varepsilon_{0}\right)
$$

where $\sigma$ is the conductivity, and $\omega$ is the frequency.

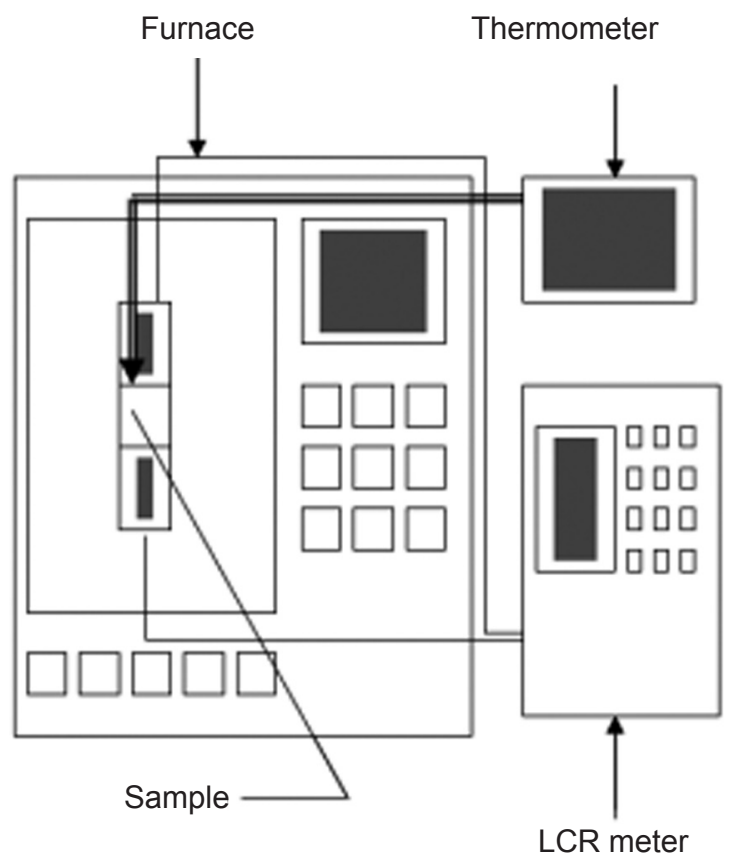

Figure 1: Test setup schematic for capacitance and loss factor measurements.

[Figura 1: Esquema do arranjo de ensaio para medições de capacitância e fator de perda.]

\section{RESULTS AND DISCUSSION}

The mineralogical composition of the clays influences plasticity. The type of mineral clay and the particle size distribution as well as the quantity and the type of accessory materials alter plasticity. Iron minerals (mainly $\mathrm{Fe}_{2} \mathrm{O}_{3}$ ) and calcium minerals (mainly $\mathrm{CaCO}_{3}$ ) are among the main impurities characterized by non-plastic properties. All the raw materials used for porcelain samples production were chemically analyzed (Table I). These results indicate that kaolin, quartz and feldspar were of the common type generally used in porcelain products with moderately small amounts of impurities. In feldspar, iron oxide content is considerably lower than in conventional feldspathic fluxes $\left(\mathrm{Fe}_{2} \mathrm{O}_{3}<1 \mathrm{wt} \%\right)$. The presence of potassium oxide proportion in feldspar confirms the existence of orthoclase. The quartz contains small amounts of $\mathrm{CaO}$ and $\mathrm{Fe}_{2} \mathrm{O}_{3}$, about $1.87 \mathrm{wt} \%$ and $0.74 \mathrm{wt} \%$, respectively (Table I), contrarily to other works which were characterized by remarkable amounts of $6.78 \mathrm{wt} \% \mathrm{CaO}$ and $4.57 \mathrm{wt} \% \mathrm{Fe}_{2} \mathrm{O}_{3}$ [7]. Additionally, the SEM micrographs of the two types kaolin (KDD2 and KT2) powders used in this work are given in Fig. 2: KDD2 crystallizes nicely in the form of naturally nanorode halloysite crystals (Fig. 2a); by contrast, KT2 powder crystals had platelet form (Fig. 2b). However, $\mathrm{Fe}_{2} \mathrm{O}_{3}$ is not the only factor responsible for the coloration of ceramic wares. Other constituents such as $\mathrm{CaO}, \mathrm{MgO}, \mathrm{MnO}$ and $\mathrm{TiO}_{2}$ can appreciably modify the color of fired clays. The quantities of the components depend on the mineralogical nature of the clays, on the clay particle size distribution and finally on their reactivity to the melting minerals. These oxides $\left(\mathrm{CaO}, \mathrm{MgO}, \mathrm{MnO}\right.$ and $\left.\mathrm{TiO}_{2}\right)$ may play a significant role towards densification, phase transformation and mullite grain growth in the porcelain product. Consequently, the presence of such oxides and different raw materials such as the two kaolin types in a porcelain product and kaolinalumina-silica mixture may enhance their properties.

XRD pattern of sample sintered at $1160{ }^{\circ} \mathrm{C}$ is shown in Fig. 3a. The crystalline phases (quartz and mullite) dispersed in the vitreous phase are identified by XRD in samples fired above $1160{ }^{\circ} \mathrm{C}$. In all patterns, quartz and mullite phases were found to be the major crystalline phases. Typical bands, assigned to quartz and mullite, are distinguished in the FTIR spectrum in Fig. 3b. The absorption peaks at 459, 778 and $798 \mathrm{~cm}^{-1}$ correspond to the vibration of non-bridging oxygen (Si-O-). The peaks at 778 and $798 \mathrm{~cm}^{-1}$ correspond also to the vibration of non-bridging oxygen ( $\mathrm{Si}-\mathrm{O}-$ ) associated with $\mathrm{K}^{+}$, and the peaks 700,1081 and $1169 \mathrm{~cm}^{-1}$ correspond to the vibration of bridging oxygen ( $\mathrm{Si}-\mathrm{O}-\mathrm{Si}$ ) while the peak at 544 $\mathrm{cm}^{-1}$ corresponds to the vibration of ( $\left.\mathrm{Si}-\mathrm{O}-\mathrm{Al}\right)$ for the sample sintered at $1160{ }^{\circ} \mathrm{C}$ for $2 \mathrm{~h}$ [43-46]; this peak may belong to the mullite phase. The sharp spitted band corresponding to ( $\mathrm{Si}-\mathrm{O}-\mathrm{Si}$ ) is a diagnosis to identify quartz. The peaks at 1630 and $3454 \mathrm{~cm}^{-1}$ which are typically used to determine water content and these vibrations correspond to $\mathrm{H}-\mathrm{O}-\mathrm{H}$ [47]. Fig. 4 illustrates the morphologies of sample sintered at $1160{ }^{\circ} \mathrm{C}$ for $2 \mathrm{~h}$. This microstructure consists of angular quartz particles and secondary mullite crystals with needle shape that are clearly identified by SEM. Indeed, it confirms the results obtained by both XRD and FTIR techniques.

The variation of bulk density of samples versus sintering temperature is illustrated in Fig. 5. The obtained curve may be divided into two main stages. The first stage (from 1080 to $1160{ }^{\circ} \mathrm{C}$ ) was characterized by a sharp increase in the 
Table I - Chemical composition (wt\%) of raw materials.

[Tabela I - Composição química (\% em massa) das matérias-primas.]

\begin{tabular}{lcccccccccc}
\hline Raw material & $\mathrm{SiO}_{2}$ & $\mathrm{Al}_{2} \mathrm{O}_{3}$ & $\mathrm{TiO}_{2}$ & $\mathrm{Fe}_{2} \mathrm{O}_{3}$ & $\mathrm{~K}_{2} \mathrm{O}$ & $\mathrm{Na}_{2} \mathrm{O}$ & $\mathrm{CaO}$ & $\mathrm{MgO}$ & $\mathrm{MnO}$ & $\mathrm{I} . \mathrm{L}$. \\
\hline KDD2 & 45.29 & 38.26 & 0.39 & 0.09 & 0.30 & 0.07 & 0.20 & 0.03 & 0.19 & 15.18 \\
KT2 & 71.51 & 18.48 & 0.15 & 0.58 & 3.15 & 0.10 & 0.22 & 0.26 & - & 5.55 \\
Feldspar & 73.41 & 13.93 & 0.05 & 0.64 & 10.42 & 0.82 & 0.22 & 0.01 & - & 0.50 \\
Quartz & 93.57 & 2.12 & 0.03 & 0.74 & 0.59 & 0.48 & 1.87 & 0.28 & - & 0.32 \\
\hline
\end{tabular}
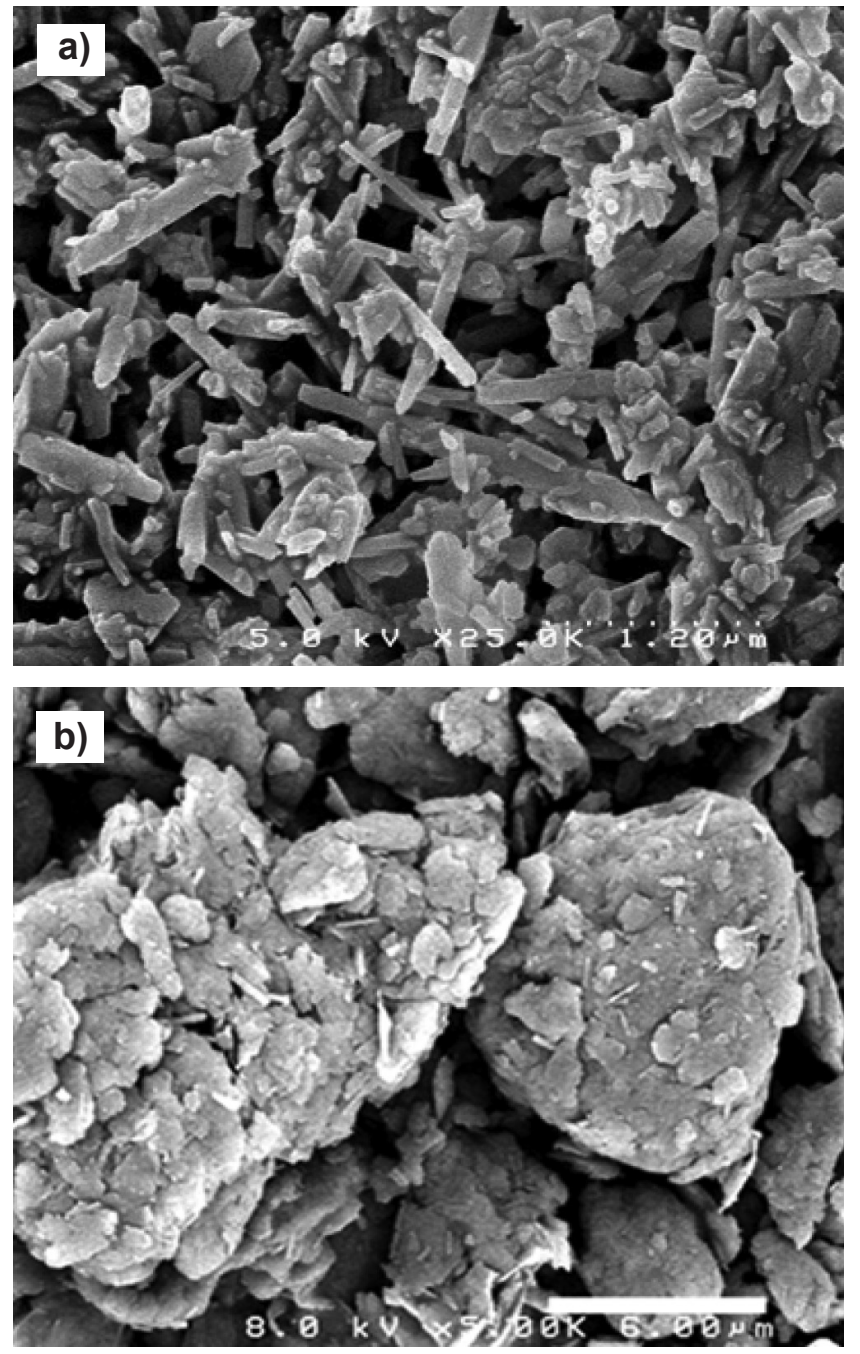

Figure 2: SEM micrographs of KDD2 (a) and KT2 (b) kaolin powders.

[Figura 2: Micrografias obtidas por microscopia eletrônica de varredura dos pós de caulim KDD2 (a) e KT2 (b).]

bulk density of samples. The bulk density reached its higher value (about $2.41 \mathrm{~g} / \mathrm{cm}^{3}$ ) for sample sintered at $1160{ }^{\circ} \mathrm{C}$ for $2 \mathrm{~h}$. Then, at the second stage $\left(1160\right.$ to $\left.1260^{\circ} \mathrm{C}\right)$ a significant decrease in bulk density was reached. This decrease in bulk density may be due to the increase in sintering temperature. Densification takes place above $1160{ }^{\circ} \mathrm{C}$, since the thermal reaction between decomposed kaolin and feldspar starts. Solid-state sintering is a process of consolidation of particles under the sintering temperatures below the melting point (1080 to $\left.1160{ }^{\circ} \mathrm{C}\right)$. Sintering during firing forms solid bonds
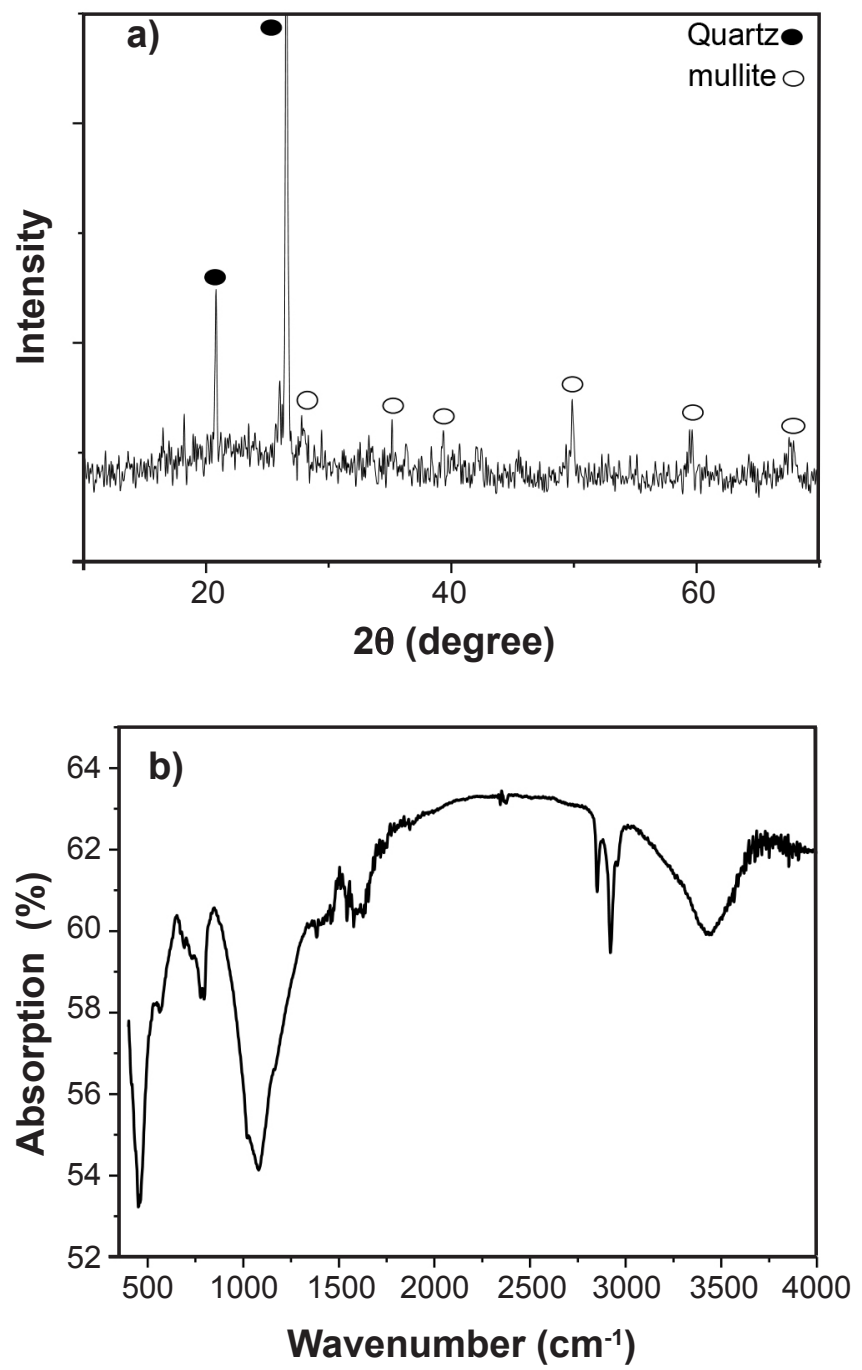

Figure 3: X-ray diffraction pattern (a) and FTIR spectrum (b) of the sample sintered at $1160{ }^{\circ} \mathrm{C}$ for $2 \mathrm{~h}$.

[Figura 3: Difratograma de raios $X(a)$ e espectro de FTIR (b) da amostra sinterizada a $1160{ }^{\circ} \mathrm{C}$ por $2 \mathrm{~h}$.]

between particles. Such bonding reduces the surface energy by reducing the free surface. In this process, the grain boundaries are partially eliminated through grain growth and the pore volume is reduced, leading to a condensed mass. The temperature necessary to induce such bonding depends upon the characteristics of both starting materials and the particle size distribution. Many theories describing various stages and transport phenomena have been proposed to describe the sintering phenomenon. Solid-state sintering takes place between particles of single or multiple phases, 


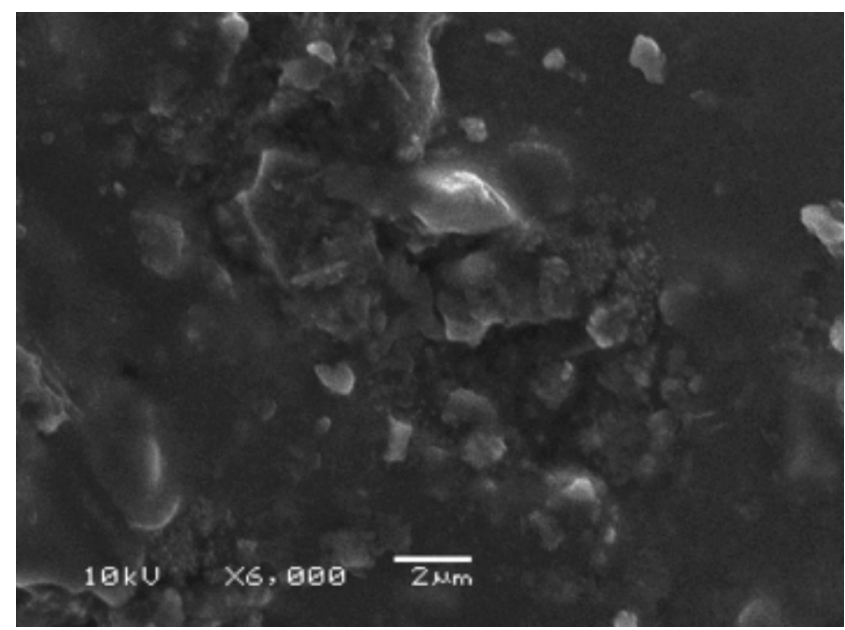

Figure 4: SEM micrograph of the sample sintered at $1160{ }^{\circ} \mathrm{C}$.

[Figura 4: Micrografia obtida por microscopia eletrônica de varredura da amostra sinterizada a $1160{ }^{\circ} \mathrm{C}$.]

where homogenization takes place during the sintering of mixed phases that form a single-phase product. However, in many cases, sintering takes place in the presence of a liquid phase, especially when many phases are present, and is known as liquid-phase sintering. The sintering behavior of the fired samples was evaluated by using the verification curves, which present the variation in properties of a ceramics as a function of firing temperature for otherwise identical firing schedules in terms of heating rate, cooling rate and holding time at peak temperatures. Densification curves help establishing the optimum firing temperature and the firing range at which the open porosity reaches a minimum, which usually corresponds to higher mechanical strength values [45]. The latter phenomenon may also be related to the formation of glassy phase which probably affects the proper interlocking of mullite needles in the microstructure [48]. At higher temperature, the lower bulk density value was due to a change in composition of the

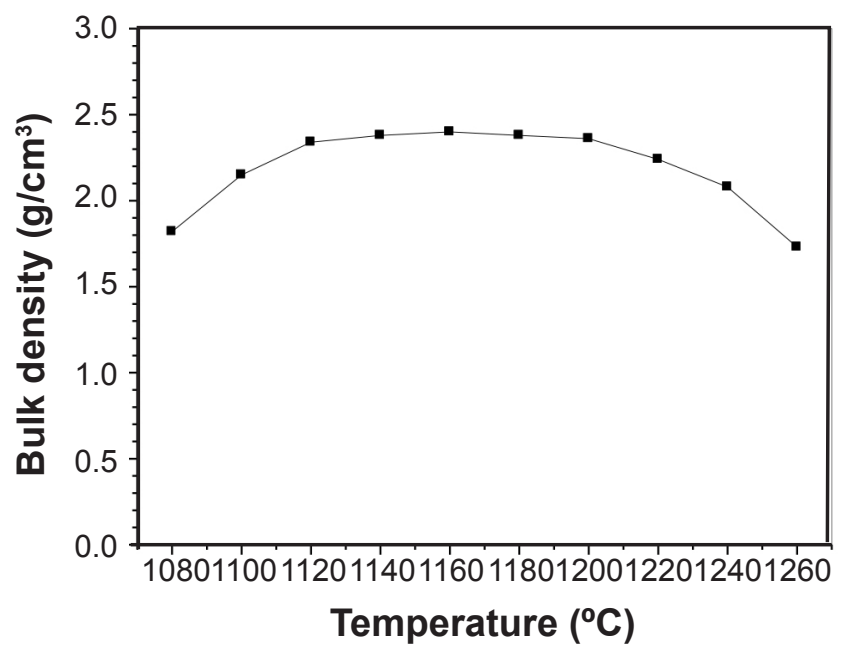

Figure 5: Bulk density of samples sintered at different temperatures for $2 \mathrm{~h}$.

[Figura 5: Densidade aparente de amostras sinterizadas em diferentes temperaturas por $2 \mathrm{~h}$. glassy phase. Elastic bond relaxation at a high sintering temperature may also be considered as a contributing factor [49]. In porcelain densification, this mechanism might be partly related to the crystallization of secondary mullite from the glassy melt but its crystal growth must be from the glassy melt. Nevertheless, its crystal growth must be limited to the optimum size. This mechanism could not be accepted as the predominant one in the densification of porcelain due to the creation of a large amount of liquid phase at maximum firing temperature which surrounds the grains completely.

The dielectric constant $\left(\varepsilon^{\prime}\right)$ of sample sintered at $1160^{\circ} \mathrm{C}$ for $2 \mathrm{~h}$, as a function of temperature measured at $1 \mathrm{kHz}$ is shown in Fig. 6a. The dielectric constant increases with the increase of temperature in temperature range from ambient to about $70{ }^{\circ} \mathrm{C}$. Thereafter, it remains fairly constant up to around $160{ }^{\circ} \mathrm{C}$ and then increases again, achieving the maximum value of about 25 . Based on a mixture rule using various theories to predict the dielectric constants of materials, the dielectric constant of the composites was found to be situated in 12-24 range [50]. In ceramic materials, ions can be used as carriers to provide electrical conduction. The degree of conductivity is largely dependent on the energy that must be given to ions to move from one lattice position to the next. At low temperatures, conductivity is low. However, if the temperature is high enough to overcome the energy barrier for lattice diffusion, the conductivity increases. Another reason which can be given is some form of interactions between the dielectric and $\mathrm{Ag}$ electrodes which may be considered as responsible for this relatively higher dielectric constant value. Moreover, the lattice defects formed could accelerate the mass transport process. The existence of lattice defects such as vacancies and interstitials in the structure helps conduction [51], and promotes grain growth furthermore. Generally, the grain size may influence the dielectric constant [52]. Dielectrics with dielectric constant above 12 are generally materials for capacitors and transducers. The porcelain sample is suitable for this application in the present form, because of its relatively high dielectric constant. The relatively high dielectric constant has to be encouraged. That was the case when the sintering of this kind of porcelain product was carried out using a microwave heating in a modified domestic multi-mode cavity [7].

The loss factor ( $\varepsilon ")$ of the sintered porcelain product as a function of temperature measured at $1 \mathrm{kHz}$ is shown in Fig. $6 \mathrm{~b}$. The increase in $\varepsilon$ " with temperature can be explained by the relaxation phenomenon which is divided into three parts: conduction loss, dipole loss and vibration loss [53]. At low temperatures, conduction losses have a minimum value. As the temperature increases conductivity increases and so do the conduction losses. As a result, the value of $\varepsilon$ " increases with the increase in temperature. The dielectric loss tangent ( $\tan \delta$ ) of the sintered porcelain product versus temperature is illustrated in Fig. 6c. The variation of $\tan \delta$ as a function of temperature at $1 \mathrm{kHz}$, for sample sintered at $1160{ }^{\circ} \mathrm{C}$, is consistent with the $\varepsilon$ " behavior (Fig. 6b). In the dielectric materials, boundaries, defects, space charge 

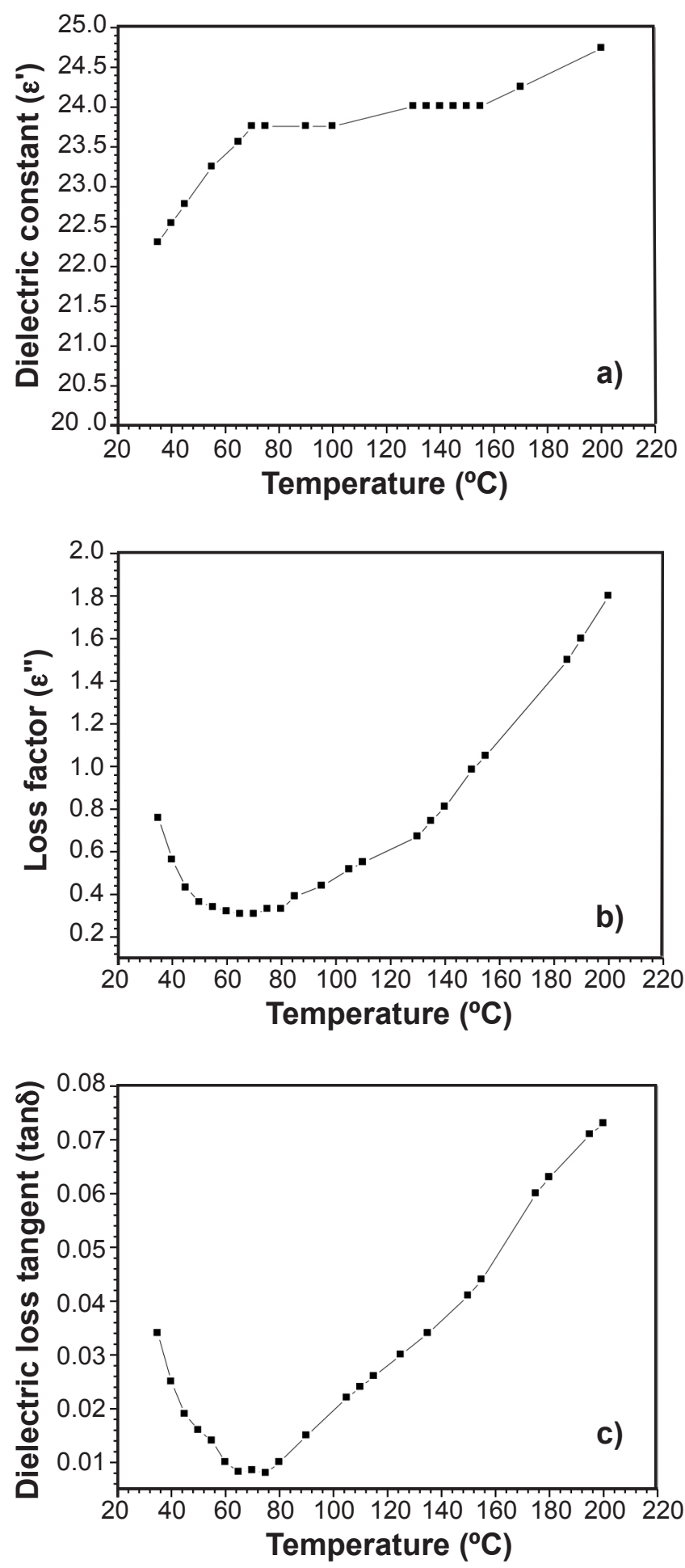

Figure 6: Dielectric constant (a), loss factor (b), and dielectric loss tangent (c) as a function of temperature for the sample sintered at $1160{ }^{\circ} \mathrm{C}$ for $2 \mathrm{~h}$.

[Figura 6: Constante dielétrica (a), fator de perda (b) e tangente de perda dielétrica (c) da amostra sinterizada a $1160{ }^{\circ} \mathrm{C}$ por $\left.2 \mathrm{~h}.\right]$

formation, lattice distortions, etc. could produce current absorption resulting in a decrease of dielectric loss tangent $(\tan \delta)$ [53]. However, the porcelain product is composed of phases such as mullite $\left(\mathrm{Al}_{6} \mathrm{Si}_{2} \mathrm{O}_{13}\right)$ and undissolved quartz
$\left(\mathrm{SiO}_{2}\right)$ crystals embedded in a continuous glassy phase, originating from feldspar [7], and may be from other low melting impurities in the raw materials. Porcelain electrical properties are generally dependent on the properties of each of these phases and impurities, at room and elevated temperatures. Chaudhuri and Parker [54] have evaluated whether the presence of mullite can influence or not the dielectric properties of porcelain using mineralizers in porcelain formulations to increase their concentrations.

The variation of resistivity of samples sintered at $1160^{\circ} \mathrm{C}$ is shown in Fig. 7. It gradually decreases with the increase in test temperature and the maximum value of the resistivity is about $9 \times 10^{13} \Omega . \mathrm{cm}$. This high value of resistivity may be attributed to the high activation energy of calcium ions which make them less mobile as reported by [55]; among the less mobile modifier ions, e.g., alkaline earth with comparatively large ions and high charge (divalent), $\mathrm{CaO}$ is one of the most effective addition for dielectric bodies. This relatively high value confirms that the technical porcelain is an insulator material because the electrical resistivity values of porcelain are also in the range of $10^{12}$ to $10^{14} \Omega . \mathrm{cm}$ [56]. The porcelain insulators are processed from three types of raw materials: plastic materials, clay or kaolin $\left[\mathrm{Al}_{2} \mathrm{Si}_{2} \mathrm{O}_{5}(\mathrm{OH})_{4}\right]$, give plasticity to the ceramic mixture; flint or quartz $\left(\mathrm{SiO}_{2}\right) /$ alumina $\left(\mathrm{Al}_{2} \mathrm{O}_{3}\right)$ maintain the shape of the formed product during firing; and feldspar $\left[\mathrm{K}_{\mathrm{x}} \mathrm{Na}_{1-\mathrm{x}}\left(\mathrm{AlSi}_{3}\right) \mathrm{O}_{8}\right]$, used as fluxing [57-60]. In the present study, the glassy phase is derived from the potash feldspar and quartz component in the porcelain composition. Glass phase has a dominant influence on electrical and dielectric properties of fired ceramics. These properties are determined by the concentration and mobility of $\mathrm{K}^{+}$and/or $\mathrm{Na}^{+}$ions in this phase [61]. In the presence of large amount of glassy phase in the structure [7], the mobile ions such as $\mathrm{K}^{+}$finds an easy path to move and hence increases the conductivity [54]. It is believed that the dielectric constant of porcelain increases with the presence of $\mathrm{K}^{+}$and $\mathrm{Na}^{+}$

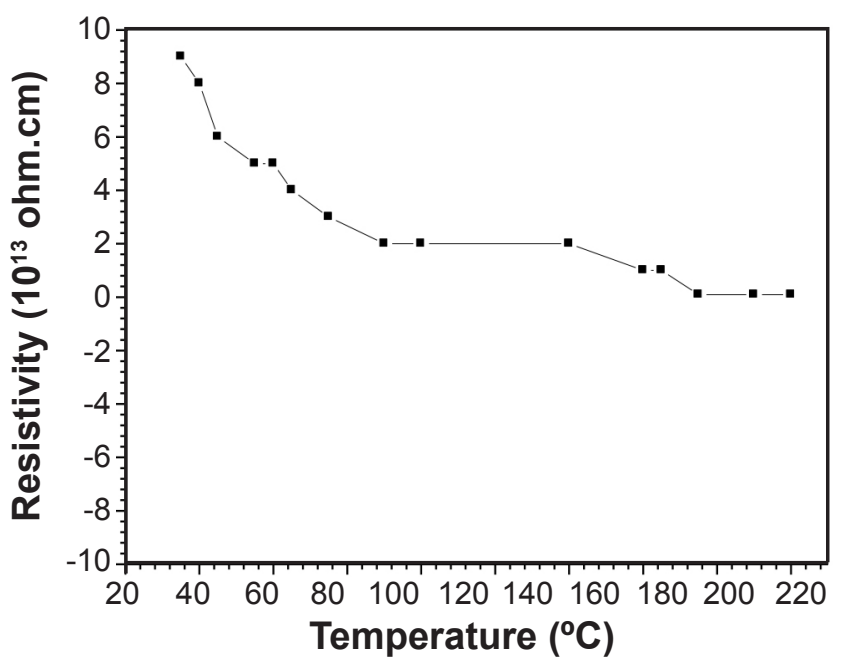

Figure 7: Variation of resistivity with temperature of sample sintered at $1160{ }^{\circ} \mathrm{C}$.

[Figura 7: Variação da resistividade com a temperatura da amostra sinterizada a $1160^{\circ} \mathrm{C}$.] 
cations and decreases when they are replaced by $\mathrm{Ca}^{2+}, \mathrm{Mg}^{2+}$ and $\mathrm{Ba}^{2+}$ cations [62]. On the other hand, mullite, which is a crystalline phase, has a vital role on electrical properties $[63,64]$.

\section{CONCLUSIONS}

The present work is an attempt for the fabrication of technical porcelains using low-price natural local raw materials. The proposed composition was $30 \mathrm{wt} \%$ kaolin (20 wt $\%$ KDD2 and $10 \mathrm{wt} \% \mathrm{KT} 2), 45 \mathrm{wt} \% \mathrm{~K}$-feldspar and $25 \mathrm{wt} \%$ quartz. According to the obtained results, the main formed crystalline phases were quartz and mullite. The optimum sintering conditions were $1160^{\circ} \mathrm{C}$ for $2 \mathrm{~h}$. Actually, the porcelain product presents dielectric constant $\left(\varepsilon^{\prime}\right)$, loss factor $(\varepsilon ")$, dielectric loss tangent $(\tan \delta$ ) and resistivity values of $22,0.8,0.035$ and $9 \times 10^{13} \Omega . \mathrm{cm}$, respectively, at room temperature. This material has potential to be used for dielectrics in commercial capacitor applications. Thus, the insulator could be used as a capacitor bushing where low charge storage capacity is desirable. The porcelain sample may be suitable for this application in the present form because of its high dielectric constant.

\section{REFERENCES}

[1] A. Harabi, S. Achour, J. Mater. Sci. Lett. 18 (1999) 955. [2] M.R. Boudchicha, S. Achour, A. Harabi, J. Mater. Sci. Lett. 20 (2001) 215.

[3] A. Mecif, J. Soro, J.P. Bonnet, A. Harabi, J. Am. Ceram. Soc. 93 (2010) 1306.

[4] A. Harabi, N. Karboua, S. Achour, Int. J. Appl. Ceram. Technol. 9 (2012) 124.

[5] A. Harabi, T.J. Davies, Br. Ceram. Trans. J. 94 (1995) 79.

[6] A. Harabi, T.J. Davies, Br. Ceram. Trans. J. 94 (1995) 97.

[7] S. Kitouni, A. Harabi, Cerâmica 57 (2011) 453.

[8] O. Toumiat, S. Achour, A. Harabi, N. Tabet, M. Boumaour, M. Maallemi, Nanotech. 17 (2006) 658.

[9] O. Bourbia, S. Achour, N. Tabet, m. Parlinska, A. Harabi, Thin Solid Films 515 (2007) 6758.

[10] F. Bouzerara, A. Harabi, S. Achour, A. Labrot, J. Eur. Ceram. Soc. 26 (2006) 1663.

[11] A. Harabi, Bouzerara, F. S. Condom, J. Des. Wat. Treat. 6 (2009) 222-226.

[12] B. Boudaira, A. Harabi, F. Bouzerara, S. Condom, J. Des. Wat. Treat. 9 (2009) 142-148.

[13] F. Bouzerara, A. Harabi, S. Condom, J. Des. Wat. Treat. 12 (2009) 415-419.

[14] A. Harabi, A. Guechi, S. Condom, J. Procedia. Eng. 33 (2012) 220-224.

[15] F. Bouzerara, A. Harabi, B. Ghouil, N. Medjemem, B. Boudaira, S. Condom, J. Procedia. Eng. 33 (2012) 278-284. [16] Y. Dong, B. Lin, J. Zhou, X. Zhang, Y. Ling, X. Liu, G. Meng, S. Hampshire, J. Mater. Charact. 62 (2011) 409-418. [17] J. Han, E. Oh, I. Song, J. Ceram. Inter. 40 (2014) 22212227.

[18] C.N. Djanganga, E. Kamseu, M. Kor Ndikontar, G.L.
Nana, J. Soro, U.C. Melo, A. Elimbi, P. Blanchart, D. Njopwouo, J. Mater. Sci. Eng. A. 528 (2011) 8311-8318.

[19] J. Ha, E. Oh, I. Song, J. Ceram. Inter. 39 (2013) 7641 7648 .

[20] Z.V. Kolpashchikova, E.V. Shcherbakova, N.S. Kostyukov, J. Glass Ceram. 60 (2003) 370-373.

[21] J.M. Amigo, J.V. Clause, E. Vicente, J.M. Delgado, M.M. Revento, L.E. Ochando, T. Debaerdemaeker, F. Marti, J. Eur. Ceram. Soc. 24 (2004) 75-81.

[22] E. Harabi, A. Harabi, L. Foughali, S. Chehlatt, S. Zouai, F.Z. Mezahi, Acta. Phys. Pol. A. 127 (2015) 1161-1163.

[23] A. Harabi, F. Zenikheri, B. Boudaira, F. Bouzerara, A. Guechi, L. Foughali, J. Eur. Ceram. Soc. 34 (2014) 1329 1340.

[24] L. Foughali, A. Harabi, S.E. Barama, F. Bouzerara, A. Guechi, B. Boudaira, J. Des. Wat. Treat. 57 (2016) 52865291.

[25] F. Bouzerara, S. Boulanacer, A. Harabi, J. Ceram. Inter. 41 (2015) 5159-5163.

[26] A. Harabi, B. Boudaira, F. Bouzerara, L. Foughali, F. Zenikheri, A. Guechi, B. Ghouil, S. Condom, J. Acta. Phys. Polonica. 127 (2015) 1164-1166.

[27] B. Boudaira, A. Harabi, F. Bouzerara, F. Zenikheri, A. Guechi, Des. Wat. Treat. 57 (2016) 5258-5265.

[28] A. Guechi, A. Harabi, S. Condom, F. Zenikheri, B. Boudaira, F. Bouzerara, L. Foughali, Des. Wat. Treat. 57 (2016) 5246-5252.

[29] B. Ghouil, A. Harabi, F. Bouzerara, Des. Wat. Treat. 57 (2016) 5241-5245.

[30] B. Ghouil, A. Harabi, F. Bouzerara, B. Boudaira, A. Guechi, M.M. Demir, A. Figoli, Mater. Charact. 103 (2015) 18-27.

[31] A. Harabi, E. Harabi, S. Chehalatt, S. Zouai, N.E. Karboua, L. Foughali, Des. Wat. Treat. 57 (2016) $5297-$ 5302 .

[32] E. Harabi, A. Harabi, F.Z. Mezahi, S. Zouai, N.E. Karboua, S. Chehalatt, Des. Wat. Treat. 57 (2016) $5297-$ 5302.

[33] E. Harabi, A. Harabi, L. Foughali, S. Chehlatt, S.Zouai, F.Z. Mezahi, Acta Phys. Pol. A 127 (2015) 1161-1163.

[34] L. Foughali, A. Harabi, J.P. Bonnet, D. Smith, B. Boudaira, Cerâmica 60, 356 (2014) 546-551.

[35] F.Z. Mezahi, H. Oudadesse, A. Harabi, A. LucasGirot, Y. Le Gal, H. Chaair, G. Cathelineau, J. Therm. Anal. Calorim. 95 (2009) 21.

[36] F.Z. Mezahi, H. Oudadesse, A. Harabi, A. Lucas-Girot, J. Appl. Ceram. Technol. 9 (2012) 529-540.

[37] A. Harabi, S. Chehlatt, J. Therm. Anal. Calorim. 111 (2013) 203-211.

[38] A. Harabi, D. Belamri, N. Karboua, F.Z. Mezahi, J. Therm. Anal. Calorim. 104 (2011) 283-289.

[39] A. Harabi, S. Zouai, Int. J. Appl. Ceram.Technol. 11 (2014) 31-46.

[40] S. Chehlatt, A. Harabi, E. Harabi, S. Zouai, H. Oudadesse, S.E. Barama, Des. Wat. Treat. 57 (2016) 52925296.

[41] S. Chehlatt, A. Harabi, H. Oudadesse, E. Harabi, Acta 
Phys. Pol. A 127 (2015) 925-927.

[42] A. Harabi, E. Harabi, Mater. Sci. Eng. C. 51 (2015) 206-215.

[43] R. Palanivel, G. Velraj, In. J. Pure. Appl. Phys. 45 (2007) 501-508.

[44] A.E. Lavat, M.C. Grasselli, J.E. Tasca, Ceram. Inter. 33 (2007) 1111-1117.

[45] J.A. Griggsa, J.C. Watahab, A. Kishen, J. Dent. Mater. 19 (2003) 353-358.

[46] L. Han-Xu, Q. Xiao-Sheng, T. Yong-Xin, J. China. Univ. Min. Tech. 18 (2008) 245-249.

[47] S. Bhattacharyya, S. Kumar Das, N.K. Mitra, Bull. Mater. Sci. 28 (2005) 445-452.

[48] S.T. Lundin, Trans. IV ${ }^{\text {th }}$ Int. Ceram. Congr., Florence, Italy (1954) 383-390.

[49] N. Montoya, F.J. Serrano, M. Reventós, J.M. Amigo, J. Alarcón, J. Eur. Ceram. Soc. 30 (2010) 839-846.

[50] A. Wypych, I. Bobowska, M. Tracz, A. Opasinska, S. Kadlubowski, A. Krzywania-Kaliszewska, J. Grobelny, P. Wojciechowski, J. Nanomater. 2014 (2014).

[51] A.S. Demirkiran, R. Artir, E. Avci, Ceram. Inter. 36 (2010) 917-921.

[52] Y.C. Lee, Int. J. Appl. Ceram. Techno. 7 (2010) 71-80.
[53] H.M. El-Malah, N.A. Hegab, J. Mater. Sci. 42 (2007) 332-336.

[54] S.P. Chaudhuri, P. Sarkar, Ceram. Inter. 26 (2000) 865 875.

[55] W.D. Kingery, H.K. Bowen, D.R. Uhlmann, John Wiley and Sons, New York, $2^{\text {nd }}$ Ed. (1976).

[56] D.W. Richerson, Marcel and Dekker, New York, USA, 47 (1982).

[57] W.M. Carty, U. Senapati, J. Am. Ceram. Soc. 81 (1998) 3-20.

[58] M.J. Jackson, B. Mills, Br. Ceram. Trans. 100 (2001) $1-8$

[59] C.A. Jouene, Traité de Cèramique et Matériaux Mineraux., Edition Septima, Paris (2001).

[60] C. Vittel, Pates et Glacures Céramiques, Edition Delta S.A CH-1800 VEVEY (1986).

[61] G.B. Kumar, K.Sivaiah, S. Buddhudu, Ceram. Inter. 36 (2010) 199-202.

[62] V. Tmovcova, I. Fura, F. Hanic, J. Phys Chem. Sol. 68 (2007) 1135-1139.

[63] V.P. Il'ina, Glass Ceram. 61 (2004) 195-197.

[64] R.A. Islam, Y.C. Chana, M.F. Islam, Mat. Sci. Eng. B. 106 (2004) 132-140.

(Rec. 20/10/2015, Rev. 20/03/2016, Ac. 23/05/2016) 